\title{
TECHNOSCIENCE ARTICLE
}

\section{Nutritional Potentiality of Developed Ready-to-use Multi-Nutrient Malt Mix}

\author{
Sudha Tiwari', Nandita Sarkar', Alpana Singh ${ }^{2}$ \\ 'Government M. H. College of Home Science \& Science for \\ Women, Autonomous, Jabalpur, Madhya Pradesh, India \\ ${ }^{2}$ Department of Food Science \& Technology, Jawaharlal Nehru \\ Krishi Vishwavidyalaya, Jabalpur, India \\ Study Area: Jabalpur, India \\ Coordinates: $23^{\circ} 10^{\prime} \mathrm{N} ; 79^{\circ} 56^{\prime} \mathrm{E}$
}

Keywords: Functional property, Whey protein, Biochemical properties.

\section{Introduction:}

Nutritional deficiency is a widespread problem among the Indian population affecting mostly the children, expecting women and elderly people from the weaker sections of the society. Interest to eat right and food with functional property has increased among consumers. The development of cost-effective nutrient-dense ready-to-use value-added products has long been advocated. Cereal and pulses are stapled food as the most important energy and protein source constituting $60-70 \%$ of the total food intake (Baranwal, 2017). To improve the nutritional potential of cereal and pulses, household techniques such as roasting, germination, fermentation, and malting are some of the excellent alternatives. Malting induces beneficial biochemical modif ication in plant seeds thereby enhancing the bioavailability of the nutrients and antioxidative capacity of the food. Malting increases protein content dietary $\mathrm{f}$ iber and reduces of bulk density and palatability of food, making it suitable for the children and heavy workers of various occupations. Wheat represents the most important cereals in human nutrition with the largest consumption. It contributes a good

\section{Abstract}

The present work aims to develop ready-to-use malted cereal pulse mix which could be utilized as base flour for instant convenient or weaning food. Wheat and green gram was malted, sesame seeds were roasted and Whey protein added to increase nutritional components. The malt mix was developed by mixing all the ingredients in a combination to extract maximum nutrients in a desirable way. Biochemical analysis, physical and functional properties were determined. We found no signif icant rise in protein, $\mathrm{f}$ ibre, carbohydrate and mineral except a nonsignif icant decrease in fat content. Bulk density of malted mix flour was signif icantly less $(0.75 \pm 0.1 \mathrm{~g} / \mathrm{ml})$ than unprocessed cereal pulse mix $(0.82 \pm 0.2 \mathrm{~g} / \mathrm{ml})$ which would be benef icial for growing children and diseased persons where low bulk density is desirable with more capacity to absorb water. Free radical scavenging activity (79\%) was increased upon malting however; total polyphenolic content was decreased by $7 \cdot 3 \%$. It could be concluded that malting and roasting enhances nutritional components and functional properties of the ready-to-use multinutrient malt mix developed for a low economical section to meet their nutritional demands.

proportion of nutrients in our daily diet (Hidalgo et al., 2016), whereas pulses like green gram contain $25 \%$ protein, high dietary fiber, and micronutrients. Pulses compliment cereals for limiting amino acid (lysine). Whey protein concentrate possesses a high amount of amino acids and biologically active component which supplements the diet in a beneficial way. Sesame has a superior quality of fat, high tocopherol, and lignin contributing anti-oxidant and cholesterol-lowering effects (Luo \& Xie, 2017). The food or diet with substantial anti-oxidative capacity is much required for workers engaged in mining and other occupations with the risk of high oxidative stress. By keeping the same in mind, the present works aim to develop ready-to-use malted cereal pulse mix which could be utilized as base flour for weaning food or instant convenient food for all age groups especially belonging to the weaker section of our society.

\section{Methodology:}

Collection of Raw Ingredient: wheat (variety MP-3336) was collected from our institutional research farm, Jabalpur, M.P., India. Green gram was made available from National Research for Weed Science, ICAR, Jabalpur, M.P.,

*Corresponding Author: sudhatiwari88@gmail.com 
India. Whey protein concentrate (WPC 70\%) was obtained from Mahaan Protein Limited, Delhi, India. Sesame seeds were purchased from the local market of Jabalpur, M.P., India.

Preparation of malt-mix ingredient: the whole wheat was soaked in clean water for $12 \mathrm{hr}$, kept for germination for $36 \mathrm{hr}$, followed by oven-dried, devegetated, and roasted for $15 \mathrm{~min}$ and then powdered to obtain malted flour (sieved). The green gram was soaked for $12 \mathrm{hr}$ in clean water and germinated for $24 \mathrm{hr}$. Sprouted dried green gram was devegetated and dehusked to obtain malted dhal. The deal was roasted for $15 \mathrm{~min}$ followed by grinding to get fine powder and sieved while sesame seed was roasted at $1800 \mathrm{C}$ to increase taste and functional value. Whey Protein Concentrate (WPC) was not processed and mixed as such.

Formulation of malt mix base: malt mix flour was developed by blending both the malted flour of wheat and green gram in such combination that possesses maximum desirable nutritional quality making it suitable for all age group based on the guidelines given by the Food Standards Program Codex Alimentarius Commission (FAO/WHO, 1994) on the nutritional and technical aspects of the production of formulated convenient foods (Fig.-1; Composition of RTU Malt mix).

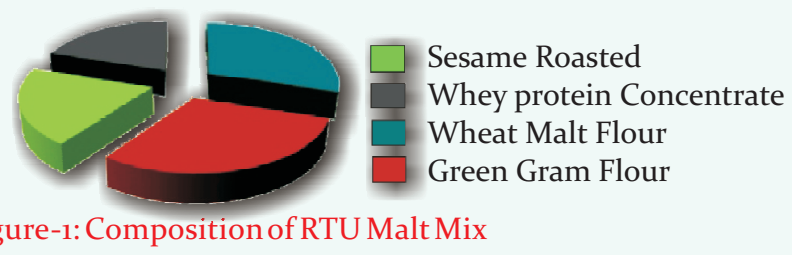

Nutritional properties of malt mix: proximate composition of wheat and green gram and sesame viz. as moisture, fat, fiber, energy estimated by AOCA (2004) methods while energy and protein content determined by Lowry's method (Lowry et al., 1951) and carbohydrate by Sadasivum \& Manickam (1992). Calcium and iron were calculated spectrophotometrically. All chemicals used were of analytical grade.

Physical properties: Physical properties of the developed malted mix such as bulk density was estimated by taking a known volume of weighted flour into a graduated cylinder filled to $10 \mathrm{ml}$ by gently tapping. The procedure was repeated three times; the average was calculated and expressed in $\mathrm{g} / \mathrm{ml}$ (Pelembe et al., 2011). Water absorption capacity (WAC) was assessed by the method of Anderson et al. (1969). Distilled water of $30 \mathrm{ml}$ at $30^{\circ} \mathrm{C}$ for suspending $2.5 \mathrm{gm}$ of flour in a centrifuge tube, constant stirring for $10 \mathrm{~min}$ at $3000 \mathrm{rpm}$ was applied. The supernatant fluid was discarded, the remaining gel was measured and expressed as gel obtained (g) by per unit gram of sample. The $\mathrm{pH}$ of the unprocessed and malt mix flour was assessed by the method of AOAC (2019). Titrable acidity was determined by titrating against $0.1 \mathrm{~N} \mathrm{NaOH}$ to phenolphthalein up to end-point and expressed as lactic acid/10o g. All analysis was carried out in triplicate and the average of the three readings was calculated.

Functional properties: the total polyphenolic content estimated by Folic-ciocalteau method of Singleton \& Rossi (1965) and antiradical scavenging activity was quantif ied by DPPH (2, 2-diphenyl-1 picrylhdrazyl) methods given by Lee et al. (2003). Gallic acid was used as a standard.

Statistical analysis: Statistical Package for Social Sciences (SPSS Version 16.0) was used for statistical analysis. Three replicates were obtained for each parameter of developed ready-to-use malt mix flour. Analysis of Variance (ANOVA) was applied to determine the difference between unprocessed wheat- green gram mix and malt flour mixes with a signif icant level of $0.05 \%$.

\section{Results and Discussion:}

Developed malt mix was analyzed for the quality in terms of nutritional, functional, and physical characteristics with different combinations of malt mix flour is discussed below.

Nutritional property of developed malt mix: nutritional composition of both types of mixes i.e., from unprocessed raw food ingredient and malted raw ingredients depicted in Fig.-1 so that the effect of malting or processing could be studied. It was found that many nutrients have signif icantly increased due to biochemical changes during malting germination in plant seeds. The moisture content of malted mix flour was signif icantly higher (9.3\%) than that unprocessed raw flour $(7.2 \%)$ which is an indication of rapid water uptake by a viable grain expected during steeping. Dry legumes absorb water rapidly, influenced by the structure of the legume. An increase in moisture content has been associated with an increase in fiber content (Akhtar et al., 2008; Elleuch et al., 2011; Maneju et al., 2011).

Table-1: Nutritional composition of RTU Malt Mix \& Unprocessed Mix (10og)

\begin{tabular}{llll}
\hline Nutrient & \multicolumn{1}{l}{ Unprocessed Mix } & Malt Mix & p value \\
\hline Moisture(g) & $7.2 \pm 1.0$ & $9.3 \pm 1.1$ & $<0.05$ \\
Protein(g) & $22.6 \pm 2.3$ & $23.5 \pm 2.1$ & $<0.05$ \\
Fat $(\mathrm{g})$ & $19.8 \pm 1.3$ & $18.1 \pm 1.5$ & $>0.05$ \\
Fibre(g) & $2.7 \pm 0.2$ & $3.0 \pm 0.3$ & $<0.05$ \\
CHO(g) & $152 \pm 3.0$ & $144 \pm 3.7$ & $<0.05$ \\
Energy(Kcal) & $387 \pm 5.7$ & $458 \pm 5.1$ & $<0.05$ \\
Calcium(mg) & $636.1 \pm 12.8$ & $641.8 \pm 15.2$ & $>0.05$ \\
Iron(mg) & $6.1 \pm 0.1$ & $6.3 \pm 0.3$ & $>0.05$ \\
\hline
\end{tabular}

The protein content of malted mix flour was significantly higher when compared with the untreated raw flour $(\mathrm{p}<0.05)$, this could be attributed to the fact that during germination step the micro-organisms in food utilized the carbohydrate content in the food sample to 
synthesis amino acid needed for their growth and development and due to breakdown of protein compounds into peptides and amino (Ade-Omowaye et al., 2006). There is a slight decrease in fat content during the germination or malting period. Similar results occurred in the study by El-Adawy et al. (2004) and Hahm et al. (2008) where the fat content decrease with an increase in the time of germination.

The carbohydrate content of germinated or malted mix flour was lower $(144 \pm 3.7 \mathrm{~g})$ than the flour of raw samples $(152 \pm 3.0 g)$. The carbohydrates may have been digested into simple sugars by amylolytic enzymes which are rapidly taken up by the growing embryo to serve as its energy source during germination (Elkhier \& Hamid,2008). The decrease in carbohydrate level is beneficial to diabetes mellitus patients. The increase in fiber $(10 \%)$ attributed to increased bran matter and the building of dry matter during the growth and development (germination) of the plant. The calorific value of the malted flour is higher $(458 \pm 5.1 \mathrm{Kcal})$ than raw flour $(387 \pm 5.7 \mathrm{Kcal})$ due to an increase in the protein content.

Calcium and iron value of the malted mix were high as calcium and iron were highest in sesame seeds (1359 $\mathrm{mg} / \operatorname{loogm}$ ). The mineral composition of the malted mix increased as compared to the unprocessed raw sample mix. Thus, malting improved the content of both the major and trace mineral ions. This observation possibly a result of enzyme solubilization and leaching of the anti-nutritional factors binding them through leaching (Idris et al., 2005; Alemu, 2009). Kaushik et al. (2010) found that germination improves calcium, copper, manganese, and zinc in legumes and cereal seeds.

Physical properties of developed malt mix: bulk density in all the blends depicted in Table-2. It was noted that malted mix flour has less density $(0.75 \pm 0.1 \mathrm{~g} / \mathrm{ml})$ than unprocessed cereal pulse mix $(0.82 \pm 0.2 \mathrm{~g} / \mathrm{ml})$ which would be benef icial for growing children and diseased persons as well with improved digestibility after malting. Bulk density represents the heaviness of flour and generally affected by particle size and flour density (Nicole et al., 2010). The low bulk density may be due to smaller particle size and is an advantage in the formulation where low bulk is desired. Water absorption capacity was noted in unprocessed sample flour was $2.39 \pm 0.1$ which increases on malting to $2.50 \pm 0.1 \mathrm{~g} /$ unit g sample significantly $(\mathrm{p}<0.05)$ indicating more ability of the flour to absorb water. Green gram contributes more to increasing water absorption capacity than other samples due to increased protein content on malting. Sub-units of proteins have more water binding sites than before (Dev \& Quensil, 1988) thereby escalating the ability of flour to form a gel of the developed malt mix. Titratable acidity in raw and malted flour mix was found to be $0.5 \pm 0.1$ and $0.6 \pm 0.1$ respectively. An increase in titratable acidity was noted while $\mathrm{pH}$ was slightly declined on malting.
Cereal and legumes are major sources of antioxidants and having hundred of chemicals with antioxidant activity and potentially beneficial effects on human health. Phenolic compounds have significant antioxidant potential and are abundant in pulses. Phenolic content ( $\mathrm{mg} / 100 \mathrm{~g}$ equivalent of Gallic acid) in malted mix flour was found to be decreased during malting by $7.3 \%$ compared to raw cereal pulse flour. The decrease in polyphenols during germination may be attributed to the polyphenol oxidase based enzymatic hydrolysis by (Megat et al., 2012).

Table-2: Physical \& Functional Properties of RTU Malt Mix $($ Mean \pm SD)

\begin{tabular}{llll}
\hline Nutrient & Unproc. Mix & Malt Mix & P value \\
\hline Bulk Density(g/ml) & $0.82 \pm 0.2$ & $0.75 \pm 0.1$ & $<0.05$ \\
Water Absorption & $2.39 \pm 0.1$ & $2.51 \pm 0.1$ & $<0.05$ \\
Capacity (g/unit g sample) & & & \\
pH & $5.1 \pm 0.3$ & $4.7 \pm 0.2$ & $<0.05$ \\
Titrable Acidity & $0.5 \pm 0.1$ & $0.6 \pm 0.1$ & $<0.05$ \\
Total Polyphenolic & $6.8 \pm 1.3$ & $6.3 \pm 1.2$ & $<0.05$ \\
Content (mg/loog) & & & \\
Anti-radical Activity (\%) & $72.4 \pm 3.1$ & $79.1 \pm 3.5$ & $<0.05$ \\
\hline
\end{tabular}

Antioxidant activity in raw food samples ranged from $21.3-36.84 \%$ with the highest activity exhibited by roasted sesame (95\%). The antioxidant activity in raw green gram was $(36 \%)$. The antioxidant activity was found to be increased the malted in wheat by $20 \%$ and $32 \%$ in mung dhal. The increase in antioxidants activity after germination seems that additional antioxidants other than polyphenols might be present cereals and legumes such as vitamins and arytenoids at different concentrations that might also behave as an antioxidant (Yang etal., 2001).

Conclusively, the present work was conducted to develop a base product for the low economical section to meet their nutritional demands and hidden deficiency at low cost than commercially fortified protein-rich supplements which should be readily available to the poor people. From the results, it can be concluded that malting and roasting enhance the nutritional components and functional properties of the multi-nutrient malt mix. The developed blended product containing malted cereal pulses with nutrient-dense sesame and dairy product (Whey protein) in the ratio of 30:30:20:20 was suitable as base material flour for supplementary food or nutrient-rich snacks as convenient food for all age group.

Acknowledgements:

University Grant Commission, India is duly acknowledged and obliged for the timely release of funds which helped the study to move ahead smoothly under the scheme of NET-JRF fellowship.

\section{References:}

Ade-Omowaye, B.I.O., Olaniyan, S.A., Adeyemi, I.A. \& Ishola, O.O. (2006): Development and quality of non-alcoholic beverages from maize based products. Nutr. Food Sci., 36 (3):183-190.

AOAC (2019): Official Method of Analysis (21st Edn). Pub. by: 


\section{TECHNOSCIENCE ARTICLE}

Association of Off icial Analytical Chemistry, Washington, DC.

Adebowale, Y.A., Adeyemi, I.A. \& Oshodi, A.A. (2005): Functional and physicochemical properties of flours of six Mucuna species. Af. J. Biotechnol., 4(12):1461-1468.

Akhtar, S., Anjum, F.M., Rehman, S.U., Sheikh, M.A. \& Farzana K. (2008): Effect of fortification on physico-chemical and microbiological stability of whole wheat flour. Food Chem., 110(1):113-119.

Alemu, K.M. (2009): The effect of natural fermentation on some antinutritional factors, minerals, proximate composition, and sensory characteristics in sorghumbased weaning foods. M.Sc thesis, Addis Ababa University, Ethiopia.

Anderson, R.A., Conway, H.F., Pfeife, V.F. \& Griffin, E.L. (1969): Roll and extrusion cooking of grain sorghum grits. Cereal Sci. Today, 14:4-12.

Baranwal, D. (2017): Malting: An indigenous technology used for improving the nutritional quality of grains - A review. Asian J. Dairy \& Food Res., 36(3):179-183.

Dev, D.K. \& Quensil, E. (1988): Preparation and Functional Properties of Linseed Protein Products Containing Differing Levels of Mucilage. J. Food Sci., 53(6):1834-1837.

El-Adawy, T.A., Rahma, E.H., El-Bedawey, A.A. \& El-Beltagy, A.E. (2004): Nutritional potential and functional properties of germinated mung bean, pea and lentil seeds. Plant Foods Human Nutr., 58:1-13.

Elkhier, M.K.S., Hamid, A.O. (2008) Effect of malting on the chemical constituents, anti-nutrition factors, and ash composition of two sorghum cultivars (Feterita and Tabat) grown in Sudan. Res. J. Agri. Biol. Sci., 4(5):500-504.

Elleuch, M., Bedigian, D., Roiseux, O., Besbes, S., Blecker, C. \& Attia, H. (2011): Dietary fibre and fibre-rich by-products of food processing: Characterisation, technological functionality and commercial applications. Rev. Food Chem., 124(2):411-421.

FAO/WHO, Guidelines on formulated supplementary foods (1994): Food Standards Program Codex Alimentarius Commission. Pub. by: Food and Agriculture Organization of the United Nations.

Hahm, T., Park, S. \& Lo, Y.M. (2008): Effects of germination on chemical composition and functional properties of sesame (Sesamum indicum L.) seeds. Bioresource Technol., 100(4):1643-1647.

Hidalgo, A., Scuppa, S. \& Brandolinib, A. (2016): Technological quality and chemical composition of puffed grains from einkorn (Triticum monococcum L. subsp. monococcum) and bread wheat (Triticum aestivum L. subsp. aestivum) LWT FoodSci. Technol., 68:541-548.

Idris, W.H., Hassan, A.B., Babikar, E.E. \& Eltinay, A.H. (2005): Effect of malt pre-treatment on antinutritional factors and $\mathrm{HCl}$ extractability of minerals of sorghum cultivars. Pak. J. Nutr., 4(6):396-401.

Kaushik, G., Satya, S. \& Naik, S.N. (2010): Effect of domestic processing techniques on the nutritional quality of the soybean. Mediter. J. Nutri. Metabol., 3(1):39-46.
Ambient Science, 2020: Vol. 07(2); 06-09 DOI:10.21276/ambi.2020.07.2.ta01

Screening of medicinal plant extracts for antioxidant activity. LifeSci., 73(2):167-179.

Lowry, O.H., Rosebrough, N.J., Farr, A.L. \& Randall, R.J. (1951): Protein measurement with Folin phenol reagent. L. Biol. Chem., 103:265-275.

Luo Y-W \& Xie W-H. (2017): Effect of germination conditions on phytic acid and polyphenols of faba bean sprouts (Vicia faba L.). Legume Res., 36(6):489-495.

Malleshi, N.G. (1995): Weaning foods. Regional extension, service center (rice milling), ministry of food processing industries, Government of India. RESC Scientif ic Series. Pub. by: Central Food and Technological Research Institute, Mysore, India. pp. 8:50.

Maneju, H., Udobi, C.E. \& Ndife, J. (2011): Effect of added brewers dry grain on the physico-chemical, microbial and sensory quality of wheat bread. Am. J. Food Nutr., 1(1):39-43.

Mbata, T.I., Ikenebomeh, M.J. \& Alaneme, J.C. (2009): Studies on the microbiological, nutrient composition, and antinutritional contents of fermented maize flour fortif ied with Bambara groundnut (Vigna subterranean L). Af. J. Food Sci., 3(6):165-171.

Megat, R.M.R. \& Azrina, A. (2012): Effect of germination on total phenolic, tannin and phytic acid contents in soybean and peanut. Int. Food Res. J., 19(2):673-677.

Mostafa, M.M., Rahma, E.H. \& Rady, A.H. (1987): Biochemical and nutritional changes in soybean during germination. L. Food Biochem., 23:257-275.

Nicole, M., Yu-Fei, H. \& Pierre. C. (2010): Characterization of ready-to-eat composite porridge flours made by soymaizesorghum- wheat extrusion cooking process. Pak. J. Nutr. 9(2):171-178.

Pelembe, L.A.M., Erasmus, C. \& Taylor, J.R.N. (2002): Development of a protein-rich composite sorghum-cowpeas instant porridge by extrusion cooking process. $\underline{L W T-F o o d ~ S c i}$ Technol., 35(2):120-127.

Sadasivam, S. \& Manickam, A. (1992): Biochemical Methods for Agricultural Sciences. Pub. By: Wiley Eastern Limited, New Delhi, India. Pp 246.

Schanderl, S.H. (1970): Methods in Food Analysis. Pub. by: Academic Press, New York. P 709.

Sanja, S.D., Sheth, N.R., Patel, N.K., Dhaval, P., Biraju, P., Sanja, S.D., Sheth, N.R., Patel, N.K. \& Patel, B. (2009): Characterization and evaluation of antioxidant activity of Portulaca oleracea. Int. J. Pharm. Pharmaceut. Sci., 1:74-84.

Singleton, V. L. \& Rossi. J.A. (1965): Colorimetry of total phenolics with phosphomolybdic-phosphotungstic acid reagents. Am. J. Enol. Viticul., 16:144-158.

Yang, F., Basu, T.K. \& Ooraikul, B. (2001): Studies on germination conditions and antioxidant contents of wheat grain. Int. J. FoodSci. Nutri., 52(4):319-330.

Lee, S.E., Hwang, H.J., Ha, J-S., Jeong, H-S. \& Kim, J.H. (2003):

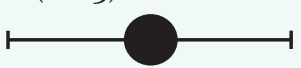

